\title{
A rho-like protein is involved in the organisation of the contractile ring in dividing sand dollar eggs
}

\author{
Issei Mabuchi ${ }^{1}$, Yukihisa Hamaguchi ${ }^{2}$, Hirotaka Fujimoto ${ }^{1}$, Narito Morii ${ }^{3}$, Masanori Mishima ${ }^{1}$ \\ and Shuh Narumiya \\ University of Tokyo, Tokyo Institute of Technology, and Kyoto University, Japan
}

\section{Summary}

Sand dollar eggs were microinjected with botulinum C3 exoenzyme, an ADP-ribosyltransferase from Clostridium botulinum that specifically ADP-ribosylates and inactivates rho proteins. C3 exoenzyme microinjected during nuclear division interfered with subsequent cleavage furrow formation. No actin filaments were detected in the equatorial cortical layer of these eggs by rhodamine-phalloidin staining. When microinjected into furrowing eggs, C3 exoenzyme rapidly disrupted the contractile ring actin filaments and caused regression of the cleavage furrows. C3 exoenzyme had no apparent effect on nuclear division, however, and multinucleated embryos developed from the microinjected eggs. By contrast, C3 exoenzyme did not affect the organisation of cortical actin filaments immediately after fertilisation. Only one protein (molecular weight 22000) was ADP-ribosylated by C3 exoenzyme in the isolated cleavage furrow. This protein co-migrated with ADP-ribosylated rhoA derived from human platelets when analysed by two-dimensional gel electrophoresis. These results strongly suggest that a rho-like, small GTP-binding protein is selectively involved in the organisation and maintenance of the contractile ring.

Keywords: Actin filaments, C3 exoenzyme, Cytokinesis, Small G-protein

\section{Introduction}

Animal cells and some lower eukaryotic cells undergo cytokinesis by means of contraction of the contractile ring that forms in the cortex of the cleavage furrow (for a review, see Mabuchi, 1986). The contractile ring is a dynamic structure composed primarily of actin filaments that rapidly organises prior to cell cleavage and disintegrates soon after contraction (Schroeder, 1972). Although it has been established that contraction is accomplished via interactions between the actin

All correspondence to: I. Mabuchi, Department of Biology, College of Arts and Sciences, University of Tokyo, 3-8-1 Komaba, Meguro-ku, Tokyo, 153, Japan. Tel: 3-3467-1171, ext. 262. Fax: 3-3485-2904.

${ }^{1}$ Department of Biology, College of Arts and Sciences, University of Tokyo, Komaba, Meguro-ku, Tokyo 153, Japan.

${ }^{2}$ Department of Biology, Faculty of Science, Tokyo Institute of Technology, Ookayama, Meguro-ku, Tokyo 152, Japan.

${ }^{3}$ Department of Pharmacology, Kyoto University Faculty of Medicine, Sakyo-ku, Kyoto 606, Japan. filaments and myosin (Mabuchi \& Okuno, 1977; Knecht \& Loomis, 1987; De Lozanne \& Spudich, 1987), many details of the structure of the contractile ring, its interaction with the plasma membrane, and mechanisms of regulation of its formation are unknown.

ADP-ribosylating enzymes have been shown to be useful tools for investigating the functions of GTPbinding proteins, since specific enzymes ADP-ribosylate and affect the function of specific target Gproteins (for a review, see Kaziro et al., 1991). Clostridium botulinum produces exoenzyme $\mathrm{C} 3$, an enzyme that ADP-ribosylates and inactivates a group of ras-related, small G-proteins termed rho proteins (Aktories et al., 1987; Narumiya \& Morii, 1993). Recent reports show that introduction of this enzyme into cultured mammalian cells causes the disappearance of stress fibres and induces the cells to round up (Chardin et al., 1989; Rubin et al., 1988; Paterson et al., 1990; Ridley \& Hall, 1992). These data suggest that a rho protein may function in the organisation and maintenance of the actin filament cytoskeleton. Here, 
we show that microinjection of $\mathrm{C} 3$ exoenzyme into sand dollar eggs interferes with cellular cleavage by affecting the structure of the contractile ring.

\section{Materials and methods}

\section{Materials}

Eggs of the sand dollars Clypeaster japonicus and Scaphechinus mirabilis were obtained by injection of $1 \mathrm{mM}$ acetylcholine chloride into the body cavity. They were fertilised in ordinary sea water and fertilisation membranes were removed by treatment with $1 \mathrm{M}$ urea (Mabuchi \& Takano-Ohmuro, 1990). The eggs were cultured at $20^{\circ} \mathrm{C}$ in ordinary sea water.

\section{Microinjection of $\mathrm{C} 3$ exoenzyme}

Recombinant C3 exoenzyme from Clostridium botulinum was prepared as described previously (Nemoto et al., 1991) and dissolved at a concentration of $1.06 \mathrm{mg} / \mathrm{ml}$ in $0.15 \mathrm{M} \mathrm{NaCl} / 20 \mathrm{mM}$ Hepes buffer, $\mathrm{pH}$ 7.5. The eggs, either fertilised or unfertilised, were microinjected using a braking micropipette (Hiramoto, 1974) with recombinant C3 exoenzyme using an Optiphot microscope equipped with a DIC apparatus (Nikon, Tokyo, Japan). A Fluor 40 objective lens was used.

\section{Fluorescence microscopy}

Eggs microinjected with C3 exoenzyme were collected, briefly washed with Ca-free sea water and processed for fluorescence microscopy as described previously (Mabuchi \& Takano-Ohmuro, 1990) with minor modifications. The eggs were immobilised on protamine-coated glass slides, and fixed in medium $\mathrm{A}$ (0.8 M glucose/0.1 M $\mathrm{KCl} / 2 \mathrm{mM} \quad \mathrm{MgCl}_{2} / 5 \mathrm{mM}$ EGTA/10 mM Mops buffer, pH 7.4) containing 5\% (v/v) formalin at $20^{\circ} \mathrm{C}$ for $30 \mathrm{~min}$ and then in $0.2 \%$ Nonidet P-40 dissolved in 5\% formalin-medium $A$ for another $30 \mathrm{~min}$. The eggs were then washed in medium B $(0.8 \mathrm{M}$ glucose in medium A was replaced with $0.8 \mathrm{M}$ glycerol), stained in medium B containing $0.15 \mathrm{mM}$ rhodamine-phalloidin (Molecular Probes, Eugene, Ore.), $0.05 \mu \mathrm{g} / \mathrm{ml} \mathrm{4',6-diamidino-2-phenylin-}$ dole (DAPI) and 0.1 M 2-mercaptoethanol, and examined with an Optiphot microscope equipped with an epifluorescence apparatus (Nikon, Tokyo). A Fluor 20 objective lens was used.

\section{Two-dimensional electrophoresis}

Cleavage furrows were isolated from C. japonicus eggs as described previously (Yonemura et al., 1991) and incubated with recombinant C3 exoenzyme $(25 \mu \mathrm{g} / \mathrm{ml})$ in an ADP-ribosylation medium (Morii et al., 1988) consisting of $0.1 \mathrm{M}$ Tris- $\mathrm{HCl}, \mathrm{pH} 8.0 / 10 \mathrm{mM}$ thymidine $/ 10 \mathrm{mM}$ dithiothreitol $/ 10 \mathrm{mM}$ nicotinamide $/ 5 \mathrm{mM} \mathrm{MgCl}_{2} / 50 \mu \mathrm{M}^{32} \mathrm{P}^{2} \mathrm{NAD}^{+}(900 \mathrm{cpm} / \mathrm{pmol})$ at $30^{\circ} \mathrm{C}$ for $2 \mathrm{~h}$. Human platelet extracts were prepared as described previously (Nemoto et al., 1992) and processed as described above. These fractions were first resolved by either isoelectric focusing electrophoresis (IEF) as described previously (Mabuchi et al., 1988) or non-equilibrium pH gradient gel electrophoresis (NEpHGE) according to O'Farrell et al. (1977). These first-dimensional tube gels were placed in tandem on a second-dimensional slab gel and electrophoresed in the presence of sodium dodecyl sulphate (SDS). The final two-dimensional gels were autoradiographed.

\section{Results}

\section{C3 exoenzyme inhibits cleavage}

Recombinant C3 exoenzyme was microinjected into fertilised eggs of Clypeaster japonicus and Scaphechinus mirabilis. Injection of more than $3 \mu \mathrm{g} / \mathrm{ml}$ (final intracellular concentration) into the eggs during the period between nuclear membrane breakdown and the end of anaphase interfered with cleavage furrow formation in each of $21 \mathrm{C}$. japonicus and $78 \mathrm{~S}$. mirabilis eggs tested. By contrast, chromosome separation and movement towards the poles of the mitotic apparatus, as well as daughter nuclei formation, occurred normally. Consequently, the injected embryos became multi-nucleated (Fig. 1). When one blastomere at the 2 -cell stage was injected, cytokinesis failed to take place in the injected cell, although the non-injected blastomere developed normally up to the blastula stage. Injection of $C 3$ exoenzyme at final concentrations lower than $0.1 \mu \mathrm{g} / \mathrm{ml}$ did not interfere with cleavage. Intracellular concentrations of C3 exoenzyme between 0.1 and $2 \mu \mathrm{g} / \mathrm{ml}$ yielded intermediary results: $25 \%$ of the eggs underwent cleavage, $58 \%$ formed furrows but then regressed, and the remainder failed to form furrows. Injection of bovine serum albumin (final concentration $10-300 \mu \mathrm{g} / \mathrm{ml}$ ) had no effect on furrow formation and cellular cleavage.

When C3 exoenzyme was injected into cleaving eggs at concentrations greater than $7.7 \mu \mathrm{g} / \mathrm{ml}$, the cleavage furrow regressed after a lag of around $1 \mathrm{~min}$ in each of $22 \mathrm{C}$. japonicus and $74 \mathrm{~S}$. milabilis eggs tested (Fig. 1B). These eggs developed into multi-nucleated embryos as described above.

\section{Contractile ring is absent from C3-injected eggs}

The organisation of actin filaments in eggs microinjected with C3 exoenzyme was examined by rhodamine-phalloidin staining. This analysis revealed a dark zone in the equatorial cortex indicating the 

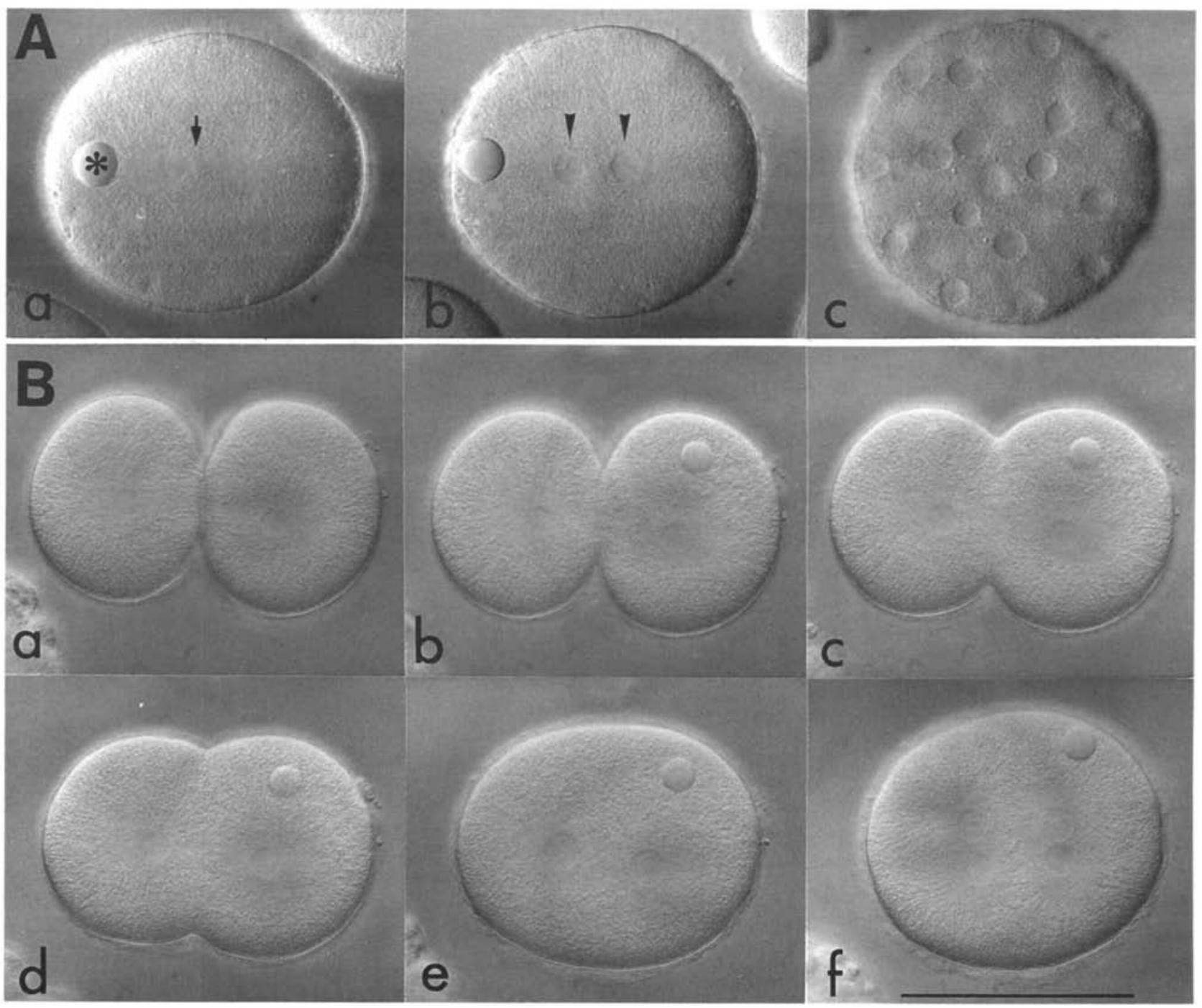

Figure 1 Microinjection of C3 exoenzyme into fertilised sand dollar eggs inhibits cell cleavage. (A) C. japonicus eggs microinjected with C3 at metaphase. (a) Immediately after microinjection of $20 \mu \mathrm{g} / \mathrm{ml} \mathrm{C3;} \mathrm{(b)} \mathrm{Same} \mathrm{egg} \mathrm{as} \mathrm{(a),} 26 \mathrm{~min}$ after injection; (c) an embryo $3.5 \mathrm{~h}$ after injection of $9.4 \mu \mathrm{g} / \mathrm{ml} \mathrm{C3}$. (B) S. mirabilis eggs microinjected with C3 during cleavage. (a) Before injection; (b) $1 \mathrm{~min}$ after injection of $12 \mu \mathrm{g} / \mathrm{ml} \mathrm{C} 3 ;(c)$ at $1 \mathrm{~min} 22 \mathrm{~s} ;(d)$ at $5 \mathrm{~min} ;(e)$ at $12 \mathrm{~min} ;(f)$ at $33 \mathrm{~min}$. Asterisk, an oil droplet introduced by microinjection; arrow, chromosomes; arrowheads, daughter nuclei. Scale bar represents $100 \mu \mathrm{m}$.

depletion of actin filaments in eggs injected between nuclear membrane breakdown and the end of anaphase as well as those injected during cleavage (Fig. 2). A similar depletion of actin filaments in the anticipated furrow region has previously been observed in sea urchin eggs cultured in the presence of ML-9, an inhibitor of myosin light chain kinase (Mabuchi \& Takano-Ohmuro, 1990).

\section{Identification of target of $\mathrm{C} 3$ in the isolated cleavage furrow}

Proteins in isolated cleavage furrows and cortices that are ADP-ribosylated by $\mathrm{C} 3$ exoenzyme were investigated by electrophoresis in two-dimensional gels. One protein spot with an apparent molecular mass of
$22 \mathrm{kDa}$ and an isoelectric point a little more basic than that of actin was observed by IEF/SDS-PAGE or NEpHGE/SDS-PAGE to be ADP-ribosylated in the isolated cleavage furrow (Fig. 3A) and in isolated cortices (not shown). We did not estimate the amount of this protein in these preparations since it was detected only by silver staining. The ADP-ribosylated $22 \mathrm{kDa}$ protein co-migrated with ADP-ribosylated rhoA in a human platelet extract (Nemoto et al., 1992) in both IEF/SDS-PAGE (Fig. 3B) and NEpHGE/SDS-PAGE (not shown).

\section{C3 does not affect actin assembly after fertilisation}

In addition to the contractile ring, a meshwork of actin filaments is also present in the cortical layer of the sea 

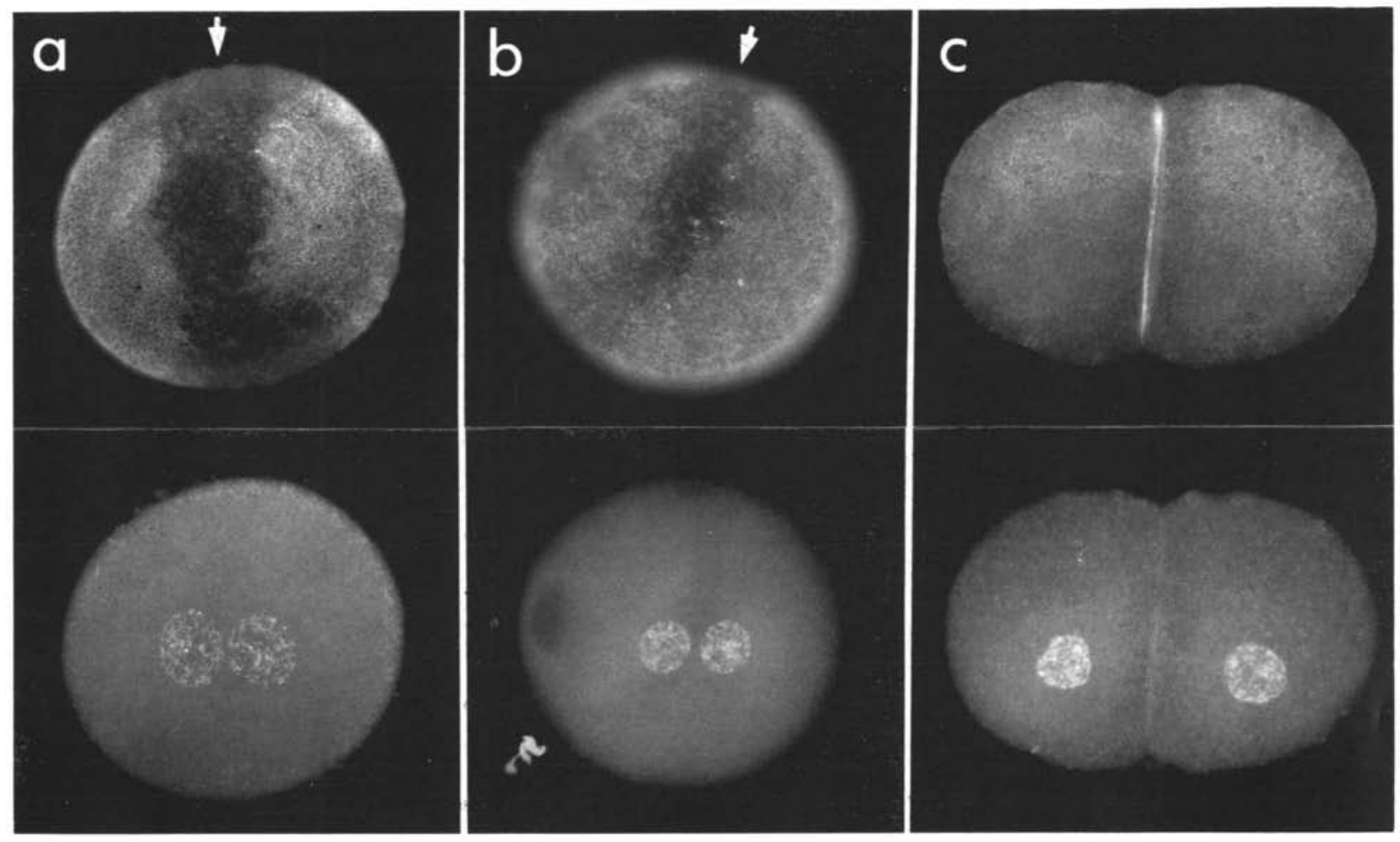

Figure 2 Organisation of actin filaments in S. mirabilis eggs microinjected with C3 exoenzyme. (a) An egg microinjected with C3 at metaphase. (b) An egg microinjected with C3 during cleavage. (c) A control egg forming the contractile ring. Upper panel, rhodamine-phalloidin staining; lower panel, DAPI staining of the corresponding eggs. Arrows, actin-depleted dark zones.

urchin and sand dollar eggs shortly after fertilisation (Yonemura \& Mabuchi, 1987; Hamaguchi \& Mabuchi, 1988). Microinjection of $C 3$ exoenzyme prior to fertilisation did not affect the organisation of these filaments, however; nor did the injection of $\mathrm{C} 3$ exoenzyme stimulate actin filament formation (Fig. 4).

\section{Discussion}

C3 exoenzyme specifically ADP-ribosylates Asn41 in rho proteins and interferes with its interaction with downstream effectors (Sekine et al., 1989; Morii et al., 1991). Another group of rho-related proteins, rac proteins, have also been reported to be ADP-ribosylated by this enzyme (Didsbury et al., 1989). Recent studies have shown, however, that rac proteins, are ADP-ribosylated 100 times to several thousand times less effectively than rho proteins (Menard et al., 1992; Ridley \& Hall, 1992). These data, in combination with our observation that the only protein in isolated cleavage furrows that is ADP-ribosylated by $\mathrm{C} 3$ exoenzyme co-migrates with human platelet rhoA, suggest that the effects of $\mathrm{C} 3$ exoenzyme observed in the present experiments can be attributed to modification of a rho-like protein. Thus, we conclude that a rho-like protein is involved in the organisation of actin filaments in the contractile ring.

Recently, the involvement of a rho protein in the organisation of cytoskeletal actin has been reported. This protein appears to be involved in stress fibre formation in cultured mammalian cells, since cells to which C3 exoenzyme or ADP-ribosylated rho is introduced tend to round up and lose their stress fibres (Rubin et al., 1988; Chardin et al., 1989; Paterson et al., $1990)$ or become unable to form stress fibres in response to serum (Ridley \& Hall, 1992). Recently, it has been shown that rho is involved not in actin polymerisation per se but in the assembly of the integrin-based adhesion site complex to which the actin filaments bind (Morii et al., 1992; Tominaga et al., 1993). It is noteworthy that the enzyme concentration required to inhibit cytokinesis is several times lower than that required to inhibit stress fibre formation in cultured mammalian cells (Ridley \& Hall, 1992). This may suggest that the contractile ring structure is more unstable than that of the stress fibre.

On the other hand, actin cytoskeleton formation occurring shortly after fertilisation was not affected by C3 exoenzyme. In cultured mammalian cells, membrane ruffling, another activity involving dynamic actin organisation, has been shown to be regulated by 


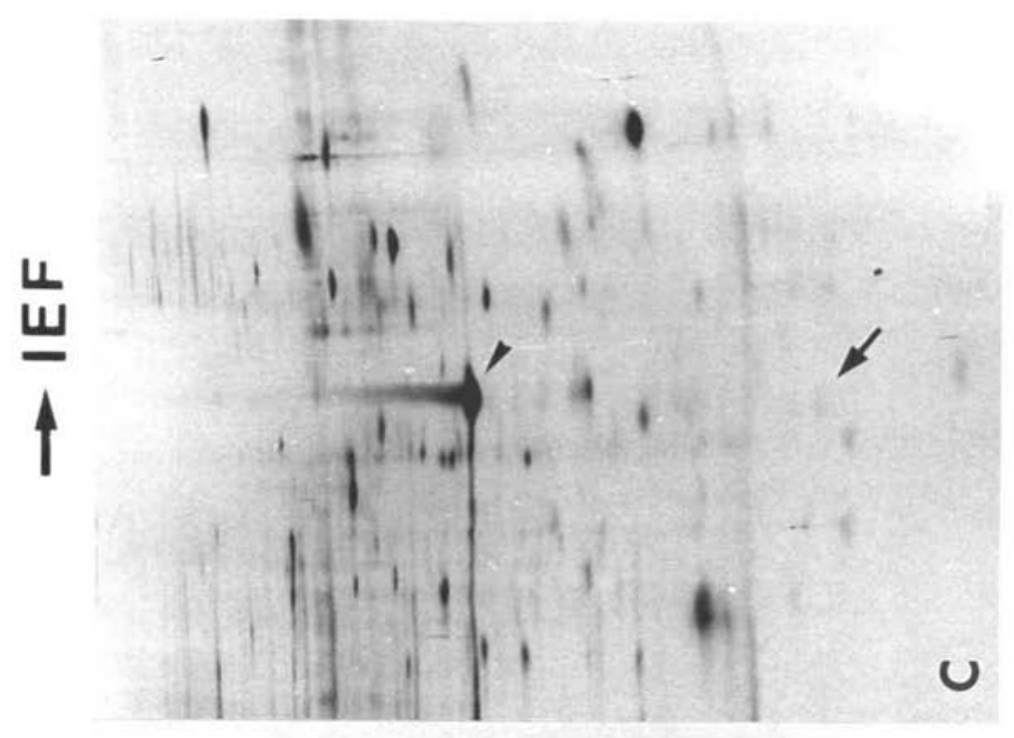

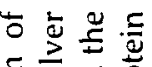

ह 5

하원동

宊苍

行

可施

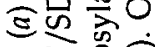

的焉票

政

ช 3

争 0

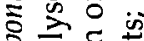

.

ن 0

돈

造

.

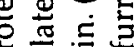

家过

3율

政

引

踏

엉

$\frac{4}{4}$

हี

$0.0<$
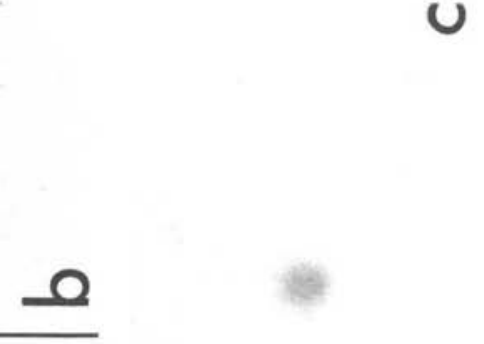

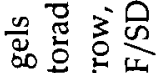

匹 究齿

总司言

语苋

월

의

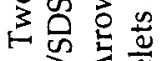

过峲

耐

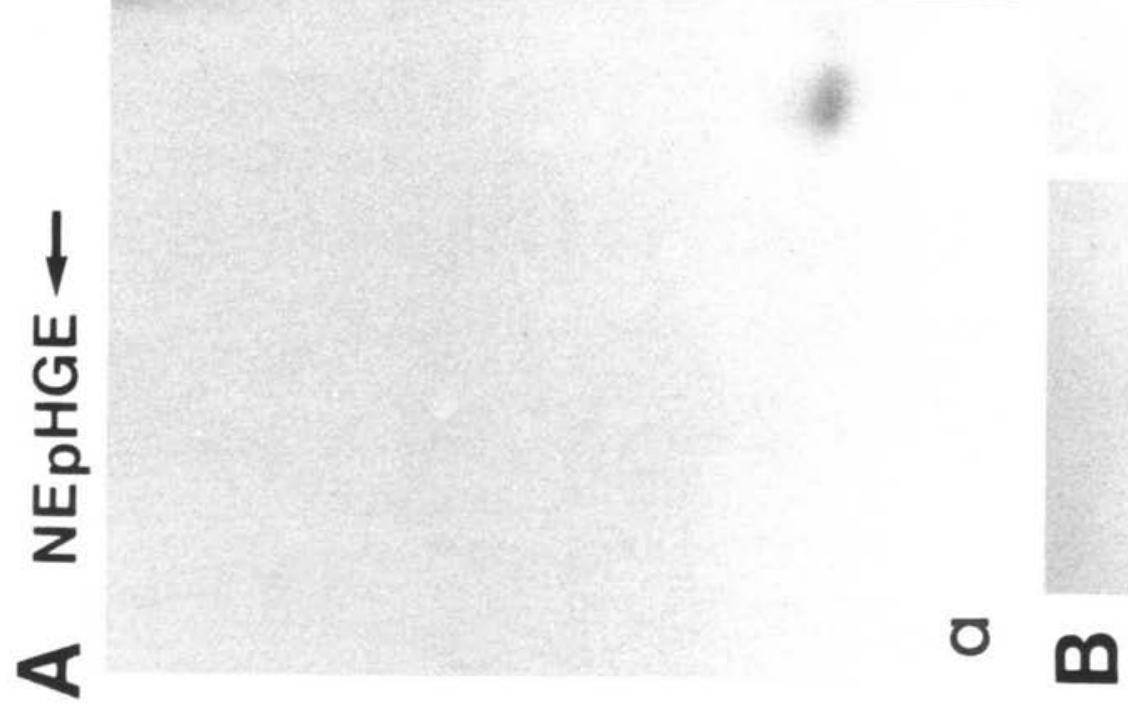

Q

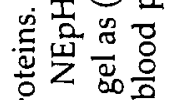

它字

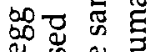

喵

듕.

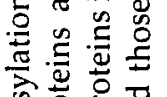

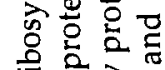

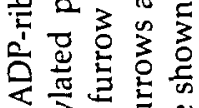

1 客宁灵

m

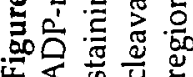



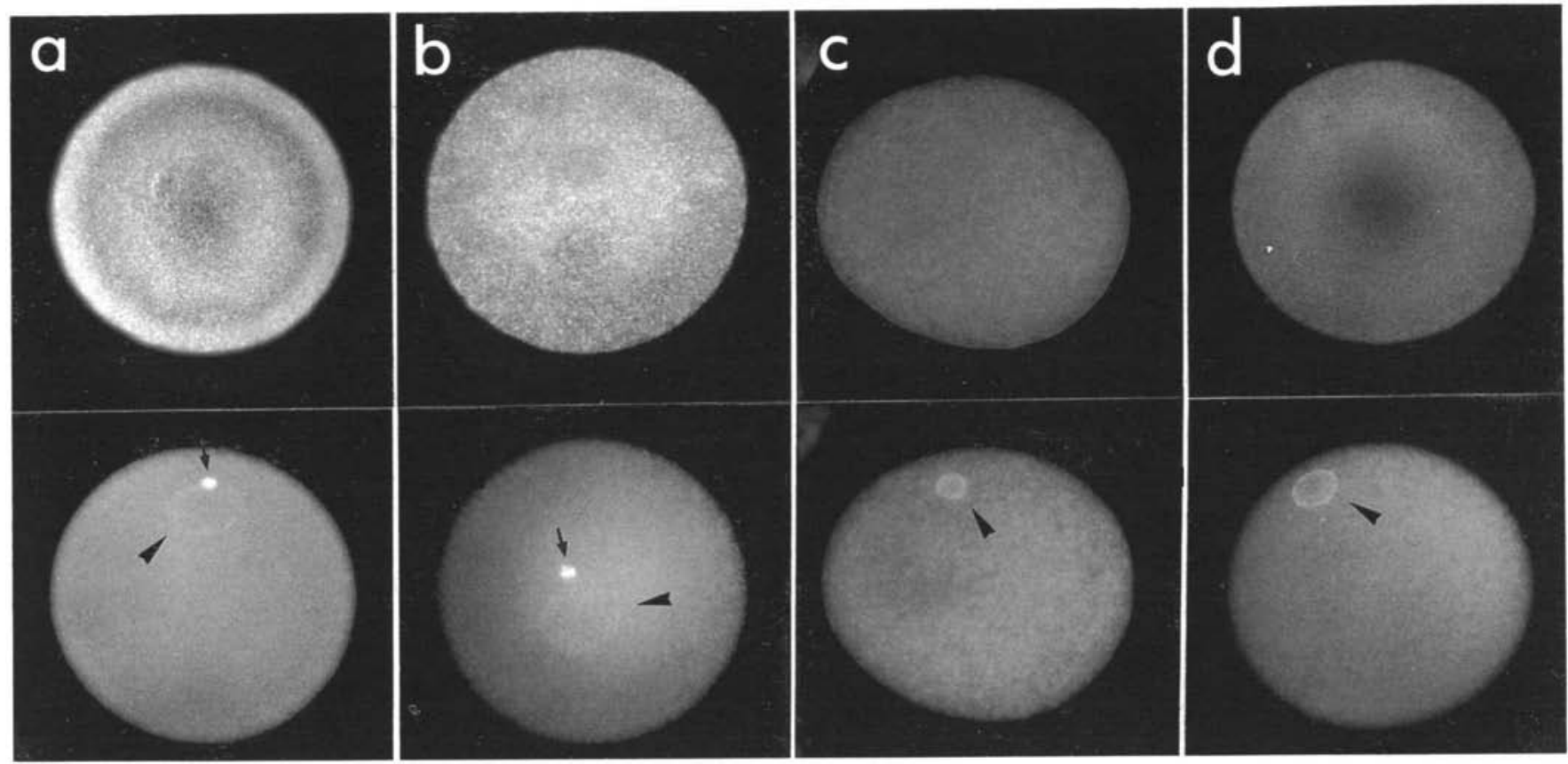

Figure 4 C3 exoenzyme does not affect actin organisation at fertilisation of S. mirabilis eggs. (a) An egg microinjected with C3, incubated for $10 \mathrm{~min}$, fertilised and fixed $15 \mathrm{~min}$ after fertilisation. (b) An egg fertilised normally and fixed 15 min after fertilisation. (c) An unfertilised egg microinjected with C3, incubated for 10 min and fixed. (d) An untreated unfertilised egg. Upper panel, rhodamine-phalloidin staining; lower panel, DAPI staining of the corresponding eggs. Arrows, sperm nuclei; arrowheads, egg nuclei.

rac proteins and not by rho (Ridley et al., 1992). Thus, different types of actin cytoskeletal organisation may be controlled by distinct small GTP-binding proteins.

The effect of $\mathrm{C} 3$ exoenzyme microinjection was dramatic and remarkably fast, causing the disassembly of the contracting contractile ring in a very short time. This was not observed when myosin-specific antibodies, which also inhibit cleavage, were injected into cleaving starfish blastomeres (Mabuchi \& Okuno, 1977). Thus, the rho-like protein appears to play a key role in contractile ring formation and stability. GTPbinding proteins serve as a molecular switches in the cell by turning on signals in transduction pathways following conversion to the GTP-bound form (Bourne et al., 1991). Recent studies on the action of rho protein in mammalian cells revealed that it also works as an intracellular switch, linking external signals to integrin activation, stress fibre formation and cell adhesion (Ridley \& Hall, 1992; Morii ct al., 1992; Tominaga et al., 1993). Cytokinesis occurs following nuclear division, and there should be some signal linking these two events (for reviews, see Mabuchi, 1986; Rappaport, 1986). The present study raises the possibility that a rho protein may be such a switch linking nuclear division with cytokinesis. How such a signal is regulated is an interesting question for future investigation.

While we were preparing the manuscript, a paper appeared which reports that injection of C3 exoenzyme into Xenopus eggs interferes with the cleavage furrow formation (Kishi et al., 1993).

\section{Acknowledgements}

We thank Dr David Saffen for reading the manuscript. This work was supported by grants to I.M. from the Ministry of Education, Culture and Science in Japan.

\section{References}

Aktories, K., Weller, U. \& Chhatwal, G.S. (1987). Clostridium botulinum type $C$ produces a novel ADP-ribosyltransferase distinct from botulinum C2 toxin. FEBS Lett. 212, 109-13.

Bourne, H.R., Sanders, D.A. \& McCormick, F. (1991). The GTPase superfamily: conserved structure and molecular mechanism. Nature 349, 117-27.

Chardin, P., Boquet, P., Maduale, P., Popoff, M.R., Rubin, E.J. \& Gill, D.M. (1989). The mammalian $G$ protein $r h o C$ is ADP-ribosylated by Clostridium botulinum exoenzyme $\mathrm{C} 3$ 
and affects actin microfilaments in Vero cells. EMBO J. 8, 1087-92.

De Lozanne, A. \& Spudich, J.A. (1987). Disruption of the Dictyostelium myosin heavy chain gene by homologous recombination. Science 236, 1086-91.

Didsbury, J., Weber, R.F., Bokoch, G.M., Evans, T. \& Snyderman, R. (1989). rac, a novel ras-related family of proteins that are botulinum toxin substrates. J. Biol. Chem. 264, 16378-82.

Hamaguchi, Y. \& Mabuchi, I. (1988). Accumulation of fluorescently labeled actin in the cortical layer in sea urchin egg after fertilization. Cell Motil. Cytoskel. 9, 153-63.

Hiramoto, Y. (1974). A method of microinjection. Exp. Cell Res. 87, 403-6.

Kaziro, Y., Ito, H., Kozasa, T., Nakafuku, M. \& Sato, T. (1991). Structure and function of signal-transducing GTP-binding proteins. Annu. Rev. Biochem. 60, 349-400.

Kishi, K., Sasaki, T., Kuroda, S., Itoh, T. \& Takai, Y. (1993). Regulation of cytoplasmic division of Xenopus embryo by rho 221 and its inhibitory GDP/GTP exchange protein (rho GDI). J. Cell Biol. 120, 1187-95.

Knecht, D.A. \& Loomis, W.F. (1987). Antisense RNA inactivation of myosin heavy chain gene expression in Dictyostelium discoideum. Science 236, 1081-6.

Mabuchi, I. (1986). Biochemical aspects of cytokinesis. Int. Rev. Cytol. 101, 175-213.

Mabuchi, I. \& Okuno, M. (1977). The effect of myosin antibody on the division of starfish blastomeres. J. Cell Biol. 74, $251-63$.

Mabuchi, I. \& Takano-Ohmuro, H. (1990). Effects of inhibitors of myosin light chain kinase and other protein kinases on the first cell division of sea urchin eggs. Dev. Growth Differ. 32, 549-56.

Mabuchi, I., Tsukita, S., Tsukita, S. \& Sawai, T. (1988). Cleavage furrow isolated from newt eggs: contraction, organization of actin filaments, and protein components of the furrow. Proc. Natl. Acad. Sci. USA 86, 5966-70.

Menard, L., Tomhave, E., Casey, P.J., Uhing, R.J., Snyderman, R. \& Didsbury, J.R. (1992). Rac1, a low-molecularmass GTP-binding-protein with high intrinsic GTPase activity and distinct biochemical properties. Eur. J. Biochem. 206, 537-46.

Morii, N., Sekine, A., Ohashi, Y., Nakao, K., Imura, H., Fujiwara, M. \& Narumiya, S. (1988). Purification and properties of the cytosolic substrate for botulinum ADPribosyltransferase. J. Biol. Chem. 263, 12420-6.

Morii, N., Kawano, K., Sekine, A., Yamada, T. \& Narumiya, S. (1991). Purification of GTPase-activating protein specific for the rho gene products. J. Biol. Chem. 266, 7646-50.

Morii, N., Teru-uchi, T., Tominaga, T., Kumagai, N., Kozaki, S., Ushikubi, F. \& Narumiya, S. (1992). A rho gene product in human blood platelets. J. Biol. Chem. 267, 20921-6.
Narumiya, S. \& Morii, N. (1993). rho gene products, botulinum C3 exoenzyme and cell adhesion. Cellular Signalling 5, 9-19.

Nemoto, Y., Namba, T., Kozaki, S. \& Narumiya, S. (1991). Clostridium botulinum C3 ADP-ribosyltransferase gene. Cloning, sequencing, and expression of a functional protein in Escherichia coli. J. Biol. Chem. 266, 19312-19.

Nemoto, Y., Namba, T., Teru-uchi, T., Ushikubi, F., Morii, N. \& Narumiya, S. (1992). A rho gene product in human blood platelets. I. Identification of the platelet substrate for botulinum C3 ADP-ribosyltransferase as rhoA protein. J. Biol. Chem. 267, 20916-20.

O'Farrell, P.Z., Goodman, H.M. \& O'Farrell, P.H. (1977). High resolution two-dimensional electrophoresis of basic as well as acidic proteins. Cell 12,1133-42.

Paterson, H.F., Self, A.J., Garrett, M.D., Just, I., Aktories, K. \& Hall, A. (1990). Microinjection of recombinant $p 21^{\text {rho }}$ induces rapid changes in cell morphology. J. Cell Biol. 111, 1001-7.

Rappaport, R. (1986). Establishment of the mechanism of cytokinesis in animal cells. Int. Rev. Cytol. 105, 245-81.

Ridley, A.J. \& Hall, A. (1992). The small GTP-binding protein rho regulates the assembly of focal adhesions and actin stress fibers in response to growth factors. Cell 70, 389-99.

Ridley, A.J., Paterson, H.F., Johnston, C.L., Diekmann, D. \& Hall, A. (1992). The small GTP-binding protein rac regulates growth factor-induced membrane ruffling. Cell 70, 401-10.

Rubin, E.J., Gill, D.M., Boquet, P. \& Popoff, M.R. (1988). Functional modification of a 21-kilodalton $G$ protein when ADP-ribosylated by exoenzyme C3 of Clostridium botulinum. Mol. Cell Biol. 8, 418-26.

Schroeder, T.E. (1972). The contractile ring. II. Determining its brief existence, volumetric changes, and vital role in cleaving Arbacia eggs. J. Cell Biol. 53, 419-34.

Sekine, A., Fujiwara, M. \& Narumiya, S. (1989). Asparagine residue in the rho gene product is the modification site for botulinum ADP-ribosyltransferase. J. Biol. Chem. 264, 8602-5.

Tominaga, T., Sugie, K., Hirata, M., Morii, N., Fukada, J., Uchida, A., Imura, H. \& Narumiya, S. (1993). Inhibition of PMA-induced, LFA-1 dependent lymphocyte aggregation by ADP ribosylation of the small molecular weight GTP binding protein, rho. J. Cell Biol. 120, 1529-37.

Yonemura, S. \& Mabuchi, I. (1987). Wave of cortical actin polymerization in the sea urchin egg. Cell Motil. Cytoskel. $7,46-53$.

Yonemura, S., Mabuchi, I. \& Tsukita, S. (1991). Mass isolation of cleavage furrows from dividing sea urchin eggs. J. Cell Sci. 100, 73-84. 